\title{
The impact of cultural tourism experience on electronic word-of-mouth (e-WOM) and destination image
}

\author{
Ardiwansyah Nanggong ${ }^{1}$ and Ali Mohammad ${ }^{2}$ \\ 1,2Department of Management, Faculty of Economics, Universitas Ichsan Gorontalo, Indonesia
}

\begin{abstract}
Tourism experience is considered highly essential in tourism studies but less attention to research has focused on cultural tourism experiences whereas has its idiosyncratic compared to other types of tourism. This study investigated the interrelationship among cultural tourism experiences, electronic word of mouth, and destination image. Empirical analysis based on data collected through online questionnaires from 134 tourists have been visited the religious-cultural tourism village Bongo in Gorontalo. PLS-SEM conducted to data analysis which showed that cultural tourism experience positively impacts on destination image and electronic word of mouth, also electronic word of mouth influence destination image. This research contributes to the body of knowledge on the role of tourism experience and its impact on future tourist behavior in the cultural tourism context. The theoretical and managerial implications of these findings are beneficial in designing strategies to leverage destination attractiveness.
\end{abstract}

\section{INTRODUCTION}

Tourism has become one of the leading sectors in national development. Indonesia has the potential to develop the tourism sector because it has an enormous natural, ethnic and cultural resources. Also, some of these opus and cultural heritage has been recognized worldwide as world cultural heritage sites. To achieve the success of tourism development, marketing, and promotion to elevate the destination image in Indonesia is essential because it can boost the level of tourist visits.

On the other side, the marketing orientation has shifted from a productdominant logic to a service-dominant logic (Vargo \& Lusch, 2004). Currently, there is an evolution in marketing thought, which has evolved from the concept of production, product, sales to the concept of experiential marketing (Tsaur, Chiu, Wang, \& Wang, 2006). This makes experiential marketing be crucial in tourism and hospitality which intangible and experience-based (Jalilvand \& Samiei, 2012; Williams, 2006; Yuan, \& $\mathrm{Wu}, 2008$ )

Generally, tourism research that focuses on tourists experiences less attention on religious cultural tourism context. Some of empirical studies on tourism experience are conducting in the context of natural tourism (Wei, Dai, Xu, \& Wang, 2020), food tourism (Jeong \& Jang, 2011), sports tourism (Sharma \& Nayak, 2018). Also the finding of Strandberg, Nath, Hemmatdar, and Jahwash, (2018) with a systematic review declare that cultural themes merely contributed $2.7 \%$ in tourism research since the millennium. Even though religious cultural tourism has its uniqueness and specificity compared to other types of tourism. Even if it is in a type of cultural tourism, each site has different characteristics because of the distinct historical backgrounds in each destination. At this point, the aspect of cultural tourism experience that consumers perceive becomes idiosyncratic. Recognizing such implications, cultural experience research is very beneficial in tourism.

Although tourism experience is considered highly essential in tourism studies, several studies have found the impact of experience that is diverse and nonspecific. For instance, behavioral intention (Coudounaris \& Sthapit, 2017; Kim, Ritchie, \& Tung, 2010). However, behavioral intention or future behavior from memorable experiences varies greatly and is common in some studies such as satisfaction (Altunel \& Erkut, 2015; Buonincontri, Morvillo, 
Okumus, \& Niekerk, 2017; Ko, Park, \& Lee, 2018), visit or revisit intention (Chen \& Rahman, 2018; Zhang, Wu, \& Buhalis, 2018), destination image (Sharma \& Nayak, 2018, 2019), e-WOM or WOM (Jeong \& Jang, 2011; Wong, Lai, \& Tao, 2019a). Therefore, further investigation of the tourist experience is needed to understand the future behavior of tourists.

Besides that, on the practical mostly the promotion of tourist destinations is driven by the tourism manager or the government as of some while emerge information bias. In today's internet era there has been an increase in the use and familiarity of online reviews a significant impact on the individual purchase behavior in various business sectors, including the tourism and hospitality industry. Hence, electronic word-of-mouth (e-WOM) can be used as an effective way of promotional tourism destinations (Ishida, Slevitch, \& Siamionava, 2016) because it involves many people and is voluntary.

According to Litvin, $\mathrm{Ng}$, and Ling, (2001), Reitsamer, Brunner-sperdin, and Stokburger-sauer, (2016), the destination attractiveness arises from the impressive personal images of experiences that travelers receive. A tourist sometimes chooses a destination that has a familiar image so information sources have a very vital role (Ishida et al., 2016; Jalilvand, 2016). In this circumstance, electronic wordof-mouth a great choice in improving the destination image. Then in a causal relationship, destination image and e-WOM are more closely related to tourism experience. The impact and importance of information sources on the destination image are often overlooked in tourism studies (Jalilvand, 2016). To our knowledge, there are still limited investigations regarding the relationship between cultural tourism experiences, e-WOM and destination image.

In addition, the relationship between the destination image and word-of-mouth by numerous studies shows different directions of both variables. For example, studies of Ishida et al. (2016), Jalilvand and Samiei, (2012) indicate that e-WOM is a predictor of destination image while research from Kim, (2018), Papadimitriou, Kaplanidou, \& Apostolopoulou, (2015) reveal that word-ofmouth is the outcome of the destination image. This shows that the pattern of relationship between the two constructs is unclear and inconclusive or sometimes contradictory.
Therefore, to fill in the gaps of previous research so that current investigations can provide a better understanding of the interrelationship of tourism experiences and future behavior in cultural tourism destinations. The main objective of this study is to offer an integrated model that examines the relationship among cultural tourism experiences, electronic word-ofmouth, and destination image.

\section{LITERATURE REVIEW AND HYPOTHESES DEVELOPMENT}

\section{Cultural tourism experience}

In literature, the term experience in business was introduced by Pine II and Gilmore, (1998) with the concept of the "experience economy". This refers to as real an offering as any service, good, or commodity which focuses on the emotional, physical, spiritual, and intellectual impressions that a person perceives in an event (Pine II \& Gilmore, 1998). Meanwhile, Schmitt, (1999) argued that experiences are individual responses that occur to stimulation, and often result from direct observation or participation in events. Then according to Tung and Ritchie, (2011) defines tourism experience as a subjective evaluation of a person in the form of affective, cognitive, and behavioral aspects of an event related to tourism activities. In general, tourism experience can be defined as an individual's response or evaluation of the events that happened in tourism activity.

The term experience in tourism studies is very diverse, for instance, religious tourism experiences (Bond, Packer, \& Ballantyne, 2014), leisure experience (Patterson \& Pegg, 2009), rural tourism experience (Carneiro, Lima, \& Silva, 2015; Kastenholz, Carneiro, Peixeira Marques, \& Lima, 2012), memorable tourism experiences (MTEs) (Kim \& Ritchie, 2014; Kim, Ritchie, \& McCormick, 2012). Scholars use the term experience based on the context of their study. Thus, in this study, the term cultural tourism experience is used since it focuses more on culture-specific dimensions. Cultural tourism experience refers to the emotional, aesthetic, cognitive, and psychological aspects obtained by tourists when visiting cultural destinations that are authentic and novelty.

The study of experience in the tourism industry emphasizes the personal aspect 
and its implications for consumer engagement. The interaction between tourists and destinations determines the impression of the experience obtained from a cultural tourism destination. The experience of cultural tourism can be obtained from destinations namely offerings historical, traditional, cultural arts, the heritage of a cultural site (Cetin \& Bilgihan, 2014; Chen \& Rahman, 2018). The cultural values contained in tourist sites can be interpreted differently by tourists even though they visit the same activities or environments (Zare, 2019).

The dimensions of cultural experience are very diverse in tourism studies. For example, a study Kay, (2009) proposes dimensions of social consumption, novelty, learn local culture, and relaxation. Then, Cetin and Bilgihan, (2014) describes aspects of social interaction, local authenticity, service, culture \& heritage, and challenges. Thereafter, Seyfi, Hall, and Rasoolimanesh, (2020) suggest the configuration of authenticity, quality of service, engagement, cultural exchange, culinary attraction.

\section{Destination image}

Destination attraction is related to some attributes and images attached to a tourist location. The emphasis on destination image is strategically in the process of selecting tourist objects based on consumer perceptions (Islam, Hossain, \& Noor, 2017; $\mathrm{Ma}, \mathrm{Hsiao}, \& \mathrm{Gao}, 2018)$. Furthermore, $\mathrm{Ma}$ et al. (2018) revealed that the components in the attractiveness of destinations include the quality of tourism products, destination image, government support, competitiveness, and convenience. Destination image and attractiveness is seen as an overall individual perception that giving an impression of a tourist location. Meanwhile, Kim, Lee, Shin, \& Yang, (2017) defines the destination image as a collection of impressions, perceptions, and beliefs of individuals about a destination. Destination image is an important topic in tourism research because it is a crucial element in evaluating destination choices and future consumer behavior (Ma et al., 2018; Ramseook-munhurrun, Seebaluck, \& Naidoo, 2015). Also, Litvin et al. (2001) argued that image is an important component in an effective product positioning strategy for tourism marketing.
A pleasant experience will affect the cognitive and affective side of image perception. Image refers to the perception of tourists in a destination as a response to the services and experiences they gain (Vengesayi, 2003). According to Beerli and Martın (2004), information obtained through personal experience or direct visits to a destination will become an individual's main image. Destination image is an important factor for an individual varies and is influenced by their personal experiences (Litvin et al., 2001; Reitsamer et al., 2016). Consequently, tourism experiences that involve the senses, emotion, and physical, play an important role for individuals in enhancing the destination image. The results of previous studies Beerli and Martın, (2004), Sharma and Nayak, (2019) also show a significant effect of tourism experience on the image of a destination. Therefore, the experiences gained by tourists will have an positive impact on the image and attractiveness of tourist destinations. So that the hypothesis proposed is:

\section{H1: Culture tourism experience positively affects on destination image.}

\section{Electronic word-of-mouth (E-WOM)}

The development and massive of use information technology the internet have transformed the model of communication in sharing information and opinions from business-to-consumer towards consumerto-consumer (Litvin, Goldsmith, \& Pan, 2008). In this context, the concept of electronic word-of-mouth (e-WOM) is highly considered and influential in the tourism industry (Litvin et al., 2008). E-WOM is defined as a model of informal communication to consumers through internet-based technology regarding the sale of products and services (Jalilvand \& Samiei, 2012; Litvin et al., 2008). Basically, e-WOM is an extension of the conventional word-of-mouth on the internet (Park, Wang, Yao, \& Kang, 2011). E-WOM is developing into a new media channel with a social networking platform where consumers share experiences, information, and advice online for destination reviews. The e-WOM concept is also often referred to as online reviews, online recommendations, or online opinions, which has become fundamental with the 
emergence of new technologies (Cantallops \& Salvi, 2014).

A literature study conducted by Sotiriadis, (2017) illustrates that the majority of tourist motives share their experiences on social media to help other tourists in making travel decisions. Consumers or tourists consider it important to know opinions from others during or before a trip (Park et al., 2011). Traveler behavior in sharing experiences and information while traveling with others so that it is useful in making travel decisions (Bae, Lee, Suh, \& Suh, 2016). The finding from Cantallops and Salvi, (2014) as well shows that the valence of e-WOM has a strong positive impact on product consideration and consumer decisions. Ladhari and Michaud, (2015) even revealed that consumers sharing information on social media are a picture of their impressions which are positively influenced by relevant experiences. Previous studies have also shown that travel experiences have an positive impact on word-of-mouth behavior on social media (Jeong \& Jang, 2011; Wong et al., 2019a; Wong, Lai, \& Tao, 2019b). Based on the description above, the hypotheses are stated as follows:

H2: Cultural tourism experience positively affects on electronic word of mouth.

According to, Kim et al. (2017) that wordof-mouth and independent sources of information are key factors for travelers in assessing the destination image. The quality of tourist information on social media like eWOM establishes the image of a tourist destination. Furthermore, Shu and Scott, (2014) also argued information content from social media is a determining factor in the destination image. Information obtained by tourists through social media will increase consumer views in assessing the image and attractiveness of tourist destinations. Several studies have also shown that electronic word-of-mouth (e-WOM) communication has an positive impact on the image of a tourist destination (Jalilvand \& Heidary, 2017; Jalilvand, Samiei, Dini, \& Manzari, 2012; Kim et al., 2017). Therefore, the above discussion built to the formation of the below-mentioned hypotheses:

H3: E-WOM positively affects on destination image.

\section{METHODS}

This study was explanatory research in nature, emphasis on studying a situation or a problem to explain and establish causal relationships among variables (Cooper \& Schindler, 2014; Saunders, Lewis, \& Thornhill, 2009). Research designed to test hypotheses and aims to confirm existing theories and use empirical research with survey techniques. Data collection using an online questionnaire. The research location of culture-religious tourism village Bongo, Gorontalo was chosen because of the consideration as a tourist destination that is familiar and identically with the concept of religious cultural tourism which is unique compared to other destinations.

The sampling technique for distributing questionnaires is purposive sampling so that respondents are selected based on certain criteria, namely first, tourists who have visited the culture tourism village of Bubohu Bongo. Second, respondents have been conducted e-WOM activities in the form of sharing their travel experiences on social media or online reviews. The number of samples collected through online questionnaires were 134 respondents. This amount is sufficient because the rule of thumb in PLS-SEM is minimum sample size should be 10 times the maximum number of arrowheads pointing at a latent variable anywhere (Hair Jr, Hult, Ringle, \& Sarstedt, 2014).

\section{Measurement}

The measurement instrument adopted the items scale from previous research. The measurement scale of cultural tourism experience consists of novelty, relaxation, social consumption, and learn local culture dimensions adapts the items scale developed from (Kay, 2009). The variable electronic word-of-mouth (e-WOM) uses 4 items from $\mathrm{Bu}$, Parkinson, and Thaichon, (2020), Harrigan, Evers, Miles, and Daly, (2017), Yang, Li, Kim, and Kim, (2015). Meanwhile, the measurement of the destination image adopted 7 scale items from the study Prayag and Ryan, (2012). The entire measurement item will be modified in the tourism context using a Likert scale 5-level point, ranging from 'strongly disagree' to 'strongly agree'. 
Table 1.

Demographic profile of respondents

\begin{tabular}{llcc}
\hline \multirow{2}{*}{ Demographic } & Categories & Proportion (total sample, $\mathbf{n}=\mathbf{1 3 4}$ \\
\cline { 2 - 4 } & Female & Frequency & Percentage \\
\hline Gender & Male & 89 & $66.4 \%$ \\
& $<21$ & 45 & $33.6 \%$ \\
\hline Age (years old) & $21-25$ & 26 & $19.4 \%$ \\
& $26-35$ & 66 & $49.3 \%$ \\
& $36-45$ & 31 & $23.1 \%$ \\
& $>46$ & 9 & $6.7 \%$ \\
\hline \multirow{2}{*}{ Education } & Junior/High School & 69 & $1.5 \%$ \\
& Junior College & 3 & $51.5 \%$ \\
& Bachelor & 57 & $2.3 \%$ \\
& Master & 5 & $42.5 \%$ \\
Profession & Student & 68 & $3.7 \%$ \\
& Private Employee & 22 & $16.4 \%$ \\
& Civil Servant & 18 & $13.4 \%$ \\
& Entrepreneur & 14 & $10.5 \%$ \\
& Other & 12 & $9 \%$ \\
\hline Resident & Inside Gorontalo & 117 & $87.3 \%$ \\
& Outside Gorontalo & 17 & $12.7 \%$ \\
\hline
\end{tabular}

\section{Data analysis}

The method of data analysis will use the Structural Equation Modeling (SEM) technique based on Partial Least Squares (PLS) to test the path model developed. PLS-SEM is considered adequate to answer research models with more than one exogenous variable with a relatively small number of samples. Assessment of good-offit the research model with two stages: first, the testing of the reliability and validity of the measurement model such as the composite reliability $>0.7$, the average variance extracted ( $\mathrm{AVE})>0.5$, and the loading factor $>0.5$ (Hair, William, Babin, \& Anderson, 2014). Second, checking the structural model by evaluating the path estimates and determination coefficient ( $R$ Square) in the bootstrapping method. In analyzing the type of mediation model is conducted by checking the significance of direct and indirect effects through the calculation of the value of the Variance Accounted For (VAF).

\section{RESULTS AND DISCUSSION}

Based on the results of the study, the demographic characteristics of the respondents were obtained including gender, age, educational background, profession, and domicile of the respondents. The demographic results of the respondents showed that the number of women was more than $66.4 \%$ while men were $33.6 \%$. The majority of respondents are young people ranging from under 35 years old as much as $92 \%$, in other words, it is dominated by the millennial generation. This shows that the need for tourism entertainment is quite high and familiar among young people. Furthermore, more respondents had junior/high school and bachelor's educational backgrounds with a percentage of $51.5 \%$ and $42.5 \%$. Most of the respondents' professions, namely $50.7 \%$, are students, while the dominant respondents come or settle within Gorontalo Province.

\section{Measurement model evaluation}

PLS-SEM requires testing of measurement models to assess the convergent and discriminant validity of a research instrument. Table 2 shown that nearly all factor loadings $>0.7$ although there are two items only above 0.5 , some scholars consider it acceptable and practically valid (Hair et al., 2014; Keil et al., 2000). 
Table 2.

Convergent validity and reliability instrument

\begin{tabular}{|c|c|c|c|c|}
\hline Variables and items & Factor loading & AVE & $\begin{array}{l}\text { Composite } \\
\text { Reliability }\end{array}$ & $\begin{array}{l}\text { Cronbach } \\
\text { alpha }\end{array}$ \\
\hline \multicolumn{2}{|c|}{ Cultural Tourism Experience (Kay, 2009) } & 0.590 & 0.963 & 0.959 \\
\hline $\begin{array}{l}\text { CE1.1 } \\
\text { CE1.2 } \\
\text { CE1.3 } \\
\text { CE1.4 } \\
\text { CE1.5 } \\
\text { CE2.1 } \\
\text { CE2.2 } \\
\text { CE2.3 } \\
\text { CE3.1 } \\
\text { CE3.2 } \\
\text { CE3.3 } \\
\text { CE3.4 } \\
\text { CE3.5 } \\
\text { CE3.6 } \\
\text { CE4.1 } \\
\text { CE4.2 } \\
\text { CE4.3 } \\
\text { CE4.4 }\end{array}$ & $\begin{array}{l}0.706 \\
0.699 \\
0.571 \\
0.785 \\
0.826 \\
0.779 \\
0.874 \\
0.866 \\
0.771 \\
0.753 \\
0.783 \\
0.704 \\
0.722 \\
0.732 \\
0.803 \\
0.785 \\
0.799 \\
0.814 \\
\end{array}$ & & & \\
\hline \multicolumn{2}{|c|}{ E-wom (Bu et al., 2020; Harrigan et al., 2017) } & 0.760 & 0.927 & 0.894 \\
\hline $\begin{array}{l}\text { Ewom01 } \\
\text { Ewom02 } \\
\text { Ewom03 } \\
\text { Ewom04 }\end{array}$ & $\begin{array}{l}0.899 \\
0.886 \\
0.857 \\
0.843 \\
\end{array}$ & & & \\
\hline \multicolumn{2}{|c|}{ Destination Image (Prayag \& Ryan, 2012) } & 0.679 & 0.936 & 0.920 \\
\hline $\begin{array}{l}\text { DIm01 } \\
\text { DIm02 } \\
\text { DIm03 } \\
\text { DIm04 } \\
\text { DIm05 } \\
\text { DIm06 } \\
\text { DIm07 }\end{array}$ & $\begin{array}{l}0.821 \\
0.875 \\
0.895 \\
0.844 \\
0.700 \\
0.843 \\
0.773 \\
\end{array}$ & & & \\
\hline
\end{tabular}

Table 3.

Discriminant validity

\begin{tabular}{l|c|c|c}
\hline & CTE & E-wom & Dest. Image \\
\hline Cultural Tourism Experience & & & \\
\hline Ewom & 0.756 & & \\
\hline Destination Image & 0.822 & 0.889 & \\
\hline
\end{tabular}

Note: HTMT values

Meanwhile, the composite reliability estimates are above 0.900 and the average variance extracted (AVE) of all the constructs was greater than 0.5 . Additionally, the Cronbach's alpha values (0.894-0.959) for all measurements indicated a confirming the internal consistency. These fit indices indicate the measurement model as shown in Table 2 has good convergent validity. To assess discriminant validity using the heterotraitmonotrait ratio of correlations (HTMT). If the
HTMT value is below 0.90 , discriminant validity has been established between other reflective constructs (Henseler, Ringle, \& Sarstedt, 2015). Overall, the outer model evaluation indicates a good-of-fit the reliability and validity of measurements.

\section{Hypothesis testing}

The structural model was estimated to fit the modeling proposed in this study. The bootstrapping technique of PLS-SEM is 
Table 4.

Result of structural model

\begin{tabular}{llllll}
\hline & Hypotheses & Path & STDEV & t value & Decision \\
\hline H1: & $\begin{array}{l}\text { Cultural Tourism Experience }-> \\
\text { Destination Image }\end{array}$ & 0.423 & 0.096 & $4.233^{\star *}$ & Supported \\
\hline H2: & $\begin{array}{l}\text { Cultural Tourism Experience }-> \\
\text { E-wom }\end{array}$ & 0.709 & 0.048 & $15.217^{\star *}$ & Supported \\
\hline H3: & E-wom $\rightarrow$ Destination Image & 0.511 & 0.089 & $5.607^{\star *}$ & Supported \\
\hline
\end{tabular}

Note: ${ }^{* *} \mathrm{p}<0.01 ; \mathrm{R} 2$ (Dest. Image $=0.747 ; \mathrm{E}-$ wom $=0.502$ )

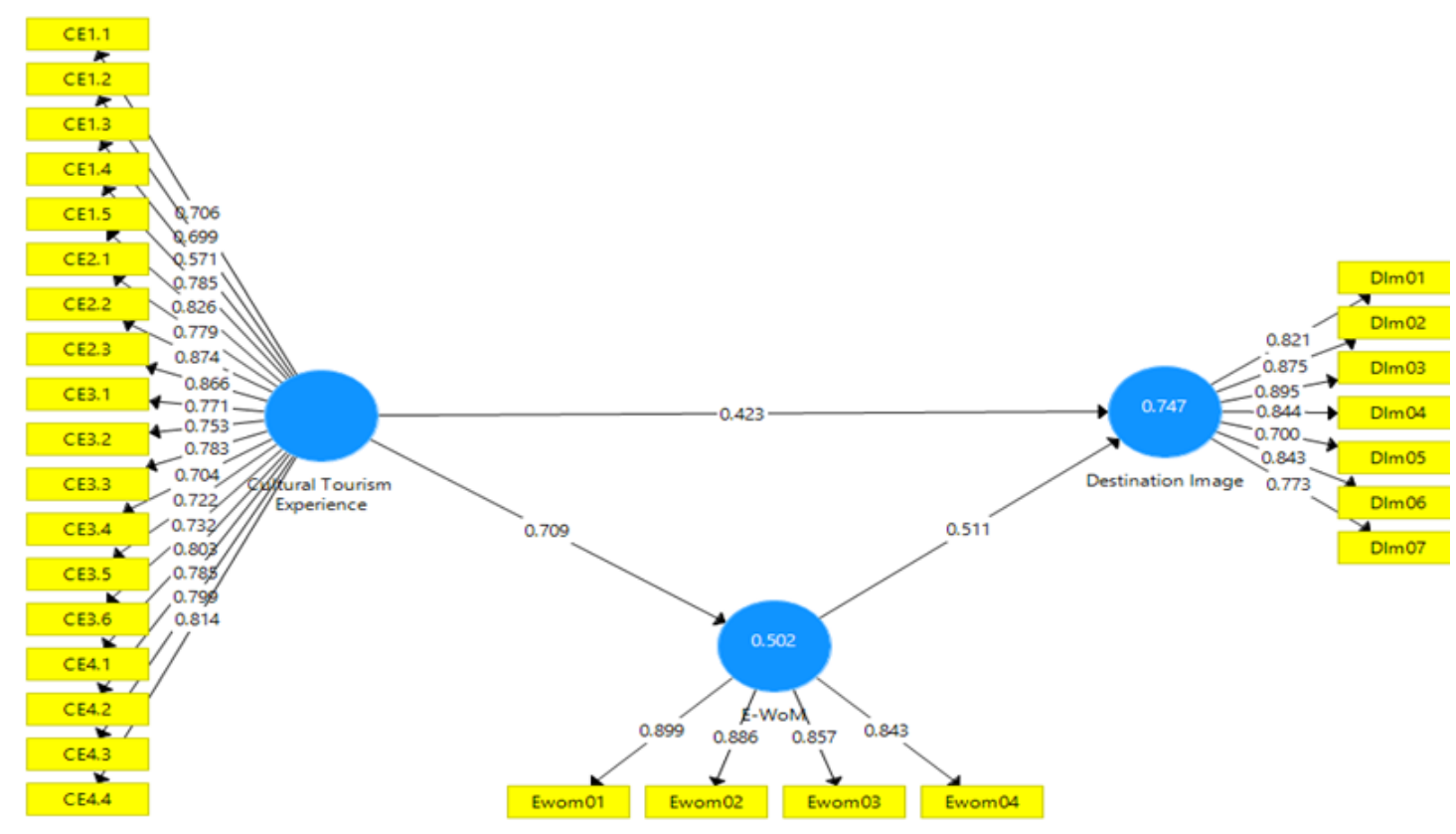

Figure 1.

Results of PLS-SEM analysis

conducted to examine the hypothesized model. Table 4 shows the results that the values of $R$ squared for e-WOM and destination images are 0.502 and 0,747 respectively. These results describe predictive power in the model proposed is good. The path coefficient estimates for hypothesis were tested showed that effect cultural tourism experience for both endogenous variables (destination image and electronic word of mouth) are significant with values $\beta=0.423 ; p<0.001$ and $\beta=$ $0.709 ; p<0.001$ respectively. This result representing that hypotheses $\mathrm{H} 1$ and $\mathrm{H} 2$ confirmed. Additionally, e-WOM also has a significant positive effect on destination image $(\beta=0.511 ; p<0.001)$ thus supporting hypothesis H3. Therefore, all the hypotheses are supported.
This study also reveals e-WOM mediated the relationships between cultural tourism experience and destination image. Based on the sequence step in mediating test, the direct and indirect effects are statistically significant. Also, according to Hair Jr et al. (2014) based on assessing the Variance Accounted For (VAF: range 20\% - 80\%) concluded e-WOM partially mediates the effects of cultural tourism experience on the destination image.

Based on the main objective of this study to assess how the relationship cultural tourism experience, electronic word of mouth, and destination image. The results of this study show that the role of tourism experience is very crucial in boosting future behavior, especially in the cultural tourism sector. The future behavior of tourists is 
Table 5.

Testing the mediating effects

\begin{tabular}{|c|c|c|c|c|c|c|}
\hline \multirow{2}{*}{ Variables } & \multirow{2}{*}{$\begin{array}{l}\text { E-wom } \\
\text { Direct }\end{array}$} & \multicolumn{2}{|c|}{ Destination Image } & \multirow[b]{2}{*}{ Total } & \multirow{2}{*}{ VAF } & \multirow{2}{*}{ Type } \\
\hline & & Direct & Indirect & & & \\
\hline CTE & 0.709 & $0.423^{\star \star}$ & $0.362^{\star *}$ & $0.786^{\star *}$ & 0.461 & Partial \\
\hline E-wom & & 0.511 & & 0.511 & & \\
\hline
\end{tabular}

manifested in electronic word of mouth and destination image. Tourism experience has both direct and indirect effects, while electronic word of mouth has a direct impact on the destination image in cultural tourism. Tourism experience has a considerable impact positively on electronic word of mouth and destination image. The findings were consistent with previous studies about the role of tourism experience in electronic word of mouth (Jeong \& Jang, 2011; Sharma \& Nayak, 2019; Wong et al., 2019b).

Our results proved the significance of tourism experience as a basis for destination image and electronic word of mouth in culture tourism. Tourists who get a unique and interesting experience from their tour will be accurate in creating the image of the destination in their minds. Experiences that may be obtained in Bubohu cultural tourism such as uniqueness, royal history, local cultural arts, scenery, relaxation. Additionally, positive tourist experiences obtained and provided by tourism destinations can spread positive e-WOM about destinations among tourists. The substantial magnitude of experience on eWOM is very likely influenced by demographic characteristics where the majority of respondents are local residents. However, native persons who are near the tourist site are more likely to be attachment personally so that their experience his feels is deeper as well as the behavior of sharing on social media.

In addition, the study results also address the inconclusive previous study debate about the direction of the relationship eWOM and destination image (Papadimitriou et al., 2015). This finding suggests that eWOM powerful predictor, so it tends to be antecedents of the destination image. Our results consistent and confirm with the previous studies (Ishida et al., 2016; Jalilvand \& Heidary, 2017; Jalilvand \& Samiei, 2012). Personal perceptions obtained by tourists from social media increase the destination image of cultural tourism objects. This is related to the intake of electronic information received so that the level of assessment and understanding of tourists create the destination image. Information from an individual's previous visit can be used as the most reliable source for potential tourists. Recommendations for other people via online are one type of important information toward destination attraction needed by tourists in traveling.

\section{CONCLUSION}

This study contributes to understanding the relationships between tourism experience, electronic word of mouth, and destination image in the culture tourism context. To best of our knowledge, no abundant empirical evidence that has investigated its model framework by the simultaneous process. The results of the study also amplify the concept of consumer value and servicedominant logic regarding the importance of preference based on an individual's situation-specific so that tourism experience becomes value-in-use during tourism activities. The findings indicated that tourism manager should design and formulate programs that a unique, interesting, and refreshing to leverage tourism experiences in the cultural destination. This is very important because it has implications for the creation of alternative promotions in the form of e-WOM behavior and destination images.

Although this research is sufficient to provide insight, it does not mean that it has no limitations. First, a recent study focus examines tourism experience in culture destination context. However, this result may not be generalized to another types of tourism or culture sites since each cultural destination has an idiosyncratic. Second, the conceptualization of the cultural tourism experience as a unidimensional construct, not consider the multidimensional variations that possibly have an impact. Hence, future 
research should include and asses the effect multidimensions construct of cultural tourism experience in a more complex model. Third, the majority of respondents is local resident may occur bias information and not representable data so that need considered proportionality sampling in future research.

\section{Acknowledgment}

The authors thank the Directorate General of Research and Development Strengthening, Ministry of Research and Technology / National Research and Innovation Agency of the Republic of Indonesia for the national competitive research grant with the scheme Penelitian Dosen Pemula (PDP) for the implementation year of 2020.

\section{REFERENCES}

Altunel, M. C., \& Erkut, B. (2015). Cultural tourism in Istanbul: The mediation effect of tourist experience and satisfaction on the relationship between involvement and recommendation intention. Journal of Destination Marketing \& Management, 1-9. https://doi.org/10.1016/j.jdmm.2015.06. 003

Bae, S. J., Lee, H., Suh, E., \& Suh, K. (2016). Shared Experience in Pretrip and Experience Sharing in Posttrip: A Survey of Airbnb Users. Information \& Management. https://doi.org/10.1016/j.im.2016.12.008

Beerli, A., \& Martın, J. D. (2004). Factors Influencing Destination Image. Annals of Tourism Research, 31(3), 657-681. https://doi.org/10.1016/j.annals.2004.01 .010

Bond, N., Packer, J., \& Ballantyne, R. (2014). Exploring Visitor Experiences, Activities and Benefits at Three Religious Tourism Sites. International Journal of Tourism Research., 17(5), 471-481. https://doi.org/10.1002/jtr

Bu, Y., Parkinson, J., \& Thaichon, P. (2020). Digital content marketing as a catalyst for e-WOM in food tourism. Australasian Marketing Journal. https://doi.org/10.1016/j.ausmj.2020.01. 001

Buonincontri, P., Morvillo, A., Okumus, F., \& Niekerk, M. Van. (2017). Managing the experience co-creation process in tourism destinations: Empirical findings from Naples. Tourism Management, 62, 264-277. https://doi.org/10.1016/j.tourman.2017. 04.014

Cantallops, A. S., \& Salvi, F. (2014). New consumer behavior: A review of research on eWOM and hotels. International Journal of Hospitality Management, 36, 41-51. https://doi.org/10.1016/j.ijhm.2013.08.0 07

Carneiro, M. J., Lima, J., \& Silva, A. L. (2015). Landscape and the rural tourism experience: identifying key elements, addressing potential, and implications for the future. Journal of Sustainable Tourism, 23(8-9), 1217-1235. https://doi.org/10.1080/09669582.2015. 1037840

Cetin, G., \& Bilgihan, A. (2014). Components of cultural tourists ' experiences in destinations. Current Issues in Tourism. https://doi.org/10.1080/13683500.2014. 994595

Chen, H., \& Rahman, I. (2018). Cultural tourism: An analysis of engagement, cultural contact, memorable tourism experience and destination loyalty. Tourism Management Perspectives, 26(April), 153-163. https://doi.org/10.1016/j.tmp.2017.10.00 6

Cooper, D. R., \& Schindler, P. S. (2014). Business Research Methods, Twelfth Edition.

Coudounaris, D. N., \& Sthapit, E. (2017). Antecedents of memorable tourism experience related to behavioral intentions. Psychology \& Marketing, 34(12), 1084-1093. https://doi.org/10.1002/mar.21048

Hair, J. F., William, C., Babin, B. J., \& Anderson, R. E. (2014). Multivariate Data Analysis Seventh Edition (7th ed.). London, England: Pearson Education Limited.

Hair Jr, J. F., Hult, G. T., Ringle, C. M., \& Sarstedt, M. (2014). A Primer Partial Least Squares Structural Equation Modeling (PLS-SEM). California: SAGE Publications.

Harrigan, P., Evers, U., Miles, M., \& Daly, T. (2017). Customer engagement with tourism social media brands. Tourism Management, 59, 597-609. https://doi.org/10.1016/j.tourman.2016. 09.015

Henseler, J., Ringle, C. M., \& Sarstedt, M. (2015). A new criterion for assessing discriminant validity in variance-based structural equation modeling. Journal of the Academy of Marketing Science, 
$43(1)$,

115-135.

https://doi.org/10.1007/s11747-0140403-8

Ishida, K., Slevitch, L., \& Siamionava, K. (2016). The Effects of Traditional and Electronic Word-of-Mouth on Destination Image: A Case of Vacation Tourists Visiting Branson, Missouri. Administrative Sciences, 6(12). https://doi.org/10.3390/admsci6040012

Islam, S., Hossain, K., \& Noor, M. E. (2017). Determining Drivers of Destination Attractiveness: The Case of NatureBased Tourism of Bangladesh. International Journal of Marketing Studies, $\quad 9(3)$, 10-23. https://doi.org/10.5539/ijms.v9n3p10

Jalilvand, M. R. (2016). Word-of-mouth vs mass media: their contributions to destination image formation. Anatolia, 2917(December), 1-12. https://doi.org/10.1080/13032917.2016. 1270840

Jalilvand, M. R., \& Heidary, A. (2017). Comparing face-to-face and electronic word-ofmouth in destination image formation: The case of Iran. Information Technology \& People, 30(4), 710-735.

Jalilvand, M. R., \& Samiei, N. (2012). The impact of electronic word of mouth on a tourism destination choice. Internet Research, 22(5), 591-612. https://doi.org/10.1108/1066224121127 1563

Jalilvand, M. R., Samiei, N., Dini, B., \& Manzari, P. Y. (2012). Examining the structural relationships of electronic word of mouth, destination image, tourist attitude toward destination and travel intention: An integrated approach. Journal of Destination Marketing \& Management, 1(1-2), 134-143. https://doi.org/10.1016/j.jdmm.2012.10. 001

Jeong, E., \& Jang, S. (2011). Restaurant experiences triggering positive electronic word-of-mouth (eWOM) motivations. International Journal of Hospitality Management, 30(2), 356366.

https://doi.org/10.1016/j.ijhm.2010.08.0 05

Kastenholz, E., Carneiro, M. J., Peixeira Marques, C., \& Lima, J. (2012). Understanding and managing the rural tourism experience - The case of a historical village in Portugal. Tourism Management Perspectives, 4, 207-214. https://doi.org/10.1016/j.tmp.2012.08.00 9
Kay, P. L. (2009). Cultural Experience Tourist Motives Dimensionality: A CrossCultural Study. Journal of Hospitality Marketing \& Management, 18(4), 329371.

https://doi.org/10.1080/1936862080259 0217

Keil, M., Tan, B. C. Y., Wei, K. K., Saarinen, T., Tuunainen, V., \& Wassenaar, A. (2000). A cross-cultural study on escalation of commitment behavior in software projects. MIS Quarterly: Management Information Systems, 24(2), 299-323. https://doi.org/10.2307/3250940

Kim, J. H. (2018). The Impact of Memorable Tourism Experiences on Loyalty Behaviors: The Mediating Effects of Destination Image and Satisfaction. Journal of Travel Research, 57(7), 856870.

https://doi.org/10.1177/0047287517721 369

Kim, J., \& Ritchie, J. R. B. (2014). Cross-Cultural Validation of a Memorable Tourism Experience Scale (MTES). Journal of Travel Research, 55(3), 323-335. https://doi.org/10.1177/0047287513496 468

Kim, J., Ritchie, J. R. B., \& McCormick, B. (2012). Development of Scale to Measure Memorable Tourism Experiences. Journal of Travel Research, 51(1), 1225. https://doi.org/10.1177/0047287510385 467

Kim, J., Ritchie, J. R. B., \& Tung, V. W. S. (2010). The Effect of Memorable Experience on Behavioral Intention in Tourism: A Structural Equation Modeling Approach. Tourism Analysis, 15, 637-648. https://doi.org/10.3727/108354210X129 04412049776

Kim, S.-E., Lee, K. Y., Shin, S. II, \& Yang, S. B. (2017). Effects of tourism information quality in social media on destination image formation: The case of Sina Weibo. Information and Management, 54(6), 687-702. https://doi.org/10.1016/j.im.2017.02.009

Ko, Y., Park, S., \& Lee, K. (2018). Railbike experience and tourist satisfaction. International Journal of Tourism Sciences, 18(1), 65-74. https://doi.org/10.1080/15980634.2018. 1439031

Ladhari, R., \& Michaud, M. (2015). eWOM effects on hotel booking intentions, attitudes , trust, and website perceptions. International Journal of Hospitality Management, $\quad 46, \quad 36-45$. 
https://doi.org/10.1016/j.jjhm.2015.01.0 10

Litvin, S. W., Goldsmith, R. E., \& Pan, B. (2008). Electronic word-of-mouth in hospitality and tourism management. Tourism Management, 29, 458-468. https://doi.org/10.1016/j.tourman.2007. 05.011

Litvin, S. W., Ng, S., \& Ling, S. (2001). The destination attribute management model: an empirical application to Bintan, Indonesia. Tourism Management, 22, 481-492.

Ma, E., Hsiao, A., \& Gao, J. J. (2018). Destination attractiveness and travel intention: the case of Chinese and Indian students in. Asia Pacific Journal of Tourism Research, $\quad O(0), \quad 1-16$. https://doi.org/10.1080/10941665.2017. 1411964

Papadimitriou, D., Kaplanidou, K., \& Apostolopoulou, A. (2015). Destination Image Components and Word-of-mouth Intentions in Urban Tourism: A Multigroup Approach. Journal of Hospitality \& Tourism Research, 42(4), 503-527.

https://doi.org/10.1177/1096348015584 443

Park, C., Wang, Y., Yao, Y., \& Kang, Y. R. (2011). Factors Influencing eWOM Effects: Using Experience, Credibility, and Susceptibility. International Journal of Social Science and Humanity, 1(1), 1-6.

Patterson, I., \& Pegg, S. (2009). Marketing the Leisure Experience to Baby Boomers and Older Tourists. Journal of Hospitality Marketing \& Management, 18, 254-272. https://doi.org/10.1080/1936862080259 4136

Pine II, J., \& Gilmore, J. H. (1998). Welcome to The Experience Economy. Harvard Business Review, 97-105.

Prayag, G., \& Ryan, C. (2012). Antecedents of Tourists' Loyalty to Mauritius: The Role and Influence of Destination Image, Place Attachment, Personal Involvement, and Satisfaction. Journal of Travel Research, (May). https://doi.org/10.1177/0047287511410 321

Ramseook-munhurrun, P., Seebaluck, V. N., \& Naidoo, P. (2015). Examining the structural relationships of destination image, perceived value, tourist satisfaction and loyalty: case of Mauritius. Procedia - Social and Behavioral Sciences, 175(230), 252-
259.

https://doi.org/10.1016/j.sbspro.2015.01 .1198

Reitsamer, F. B., Brunner-sperdin, A., \& Stokburger-sauer, N. E. (2016). Destination attractiveness and destination attachment: The mediating role of tourists' attitude. Tourism Management Perspectives, 19, 93-101. https://doi.org/10.1016/j.tmp.2016.05.00 3

Saunders, M., Lewis, P., \& Thornhill, A. (2009). Research methods for business students fifth edition (Fifth). England: Pearson Education Limited.

Schmitt, B. (1999). Experiential Marketing. Journal of Marketing Managemet, 15, 53-67.

Seyfi, S., Hall, C. M., \& Rasoolimanesh, S. M. (2020). Exploring memorable cultural tourism experiences. Journal of Heritage Tourism, 15(3), 341-357. https://doi.org/10.1080/1743873X.2019. 1639717

Sharma, P., \& Nayak, J. K. (2018). Testing the role of tourists 'emotional experiences in predicting destination image, satisfaction, and behavioral intentions: A case of wellness tourism. Tourism Management Perspectives, 28(December 2017), 41-52. https://doi.org/10.1016/j.tmp.2018.07.00 4

Sharma, P., \& Nayak, J. K. (2019). Understanding memorable tourism experiences as the determinants of tourists' behaviour. Int $\mathrm{J}$ Tourism Res, 21(4), 504-518. https://doi.org/10.1002/jtr.2278

Shu, M. L., \& Scott, N. (2014). Influence of Social Media on Chinese Students ' Choice of an Overseas Study Destination: An Information Adoption Model Perspective. Journal of Travel \& Tourism Marketing, 31(2), 286-302. https://doi.org/10.1080/10548408.2014. 873318

Sotiriadis, M. D. (2017). Sharing tourism experience in social media: A Literature Review. International Journal of Contemporary Hospital Management, 29(1), 179-225.

Strandberg, C., Nath, A., Hemmatdar, H., \& Jahwash, M. (2018). Tourism research in the new millennium: A bibliometric review of literature in Tourism and Hospitality Research. Tourism and Hospitality Research, 18(3), 269-285. https://doi.org/10.1177/1467358416642 010 
Tsaur, S., Chiu, Y., Wang, C., \& Wang, C. (2006). The Visitors Behavioral Consequences of Experiential Marketing: An Empirical Study on Taipei Zoo. Journal of Travel \& Tourism Marketing, 21(1), 47-63. https://doi.org/10.1300/J073v21n01

Tung, V. W. S., \& Ritchie, J. R. B. (2011). Exploring the Essence of Memorable Tourism Experiences. Annals of Tourism Research, 38(4), 1367-1386. https://doi.org/10.1016/j.annals.2011.03 .009

Vargo, S. L., \& Lusch, R. F. (2004). Evolving to a New Dominant Logic for Marketing. Journal of Marketing, 68(1), 1-17.

Vengesayi, S. (2003). A Conceptual Model of Tourism Destination Competitiveness and Attractieness. In ANZMAC 2003 Conference Proceedings (pp. 637-647). Adelaide.

Wei, C., Dai, S., Xu, H., \& Wang, H. (2020). Cultural worldview and cultural experience in natural tourism sites. Journal of Hospitality and Tourism Management, 43(August 2019), 241249.

https://doi.org/10.1016/j.jhtm.2020.04.0 11

Williams, A. (2006). Tourism and hospitality marketing: fantasy, feeling and fun. International Journal of Contemporary Hospital Management, 18(6), 482-495. https://doi.org/10.1108/0959611061068 1520

Wong, J. W. C., Lai, I. K. W., \& Tao, Z. (2019a). Memorable ethnic minority tourism experiences in China: a case study of Guangxi Zhuang Zu. Journal of Tourism and Cultural Change, 17(4), 508-525. https://doi.org/10.1080/14766825.2019. 1600866

Wong, J. W. C., Lai, I. K. W., \& Tao, Z. (2019b). Sharing memorable tourism experiences on mobile social media and how it influences further travel decisions. Current Issues in Tourism, 23(14), 1773-1787.

https://doi.org/10.1080/13683500.2019. 1649372

Yang, K., Li, X., Kim, H., \& Kim, Y. H. (2015). Social shopping website quality attributes increasing consumer participation, positive eWOM, and coshopping: The reciprocating role of participation. Journal of Retailing and Consumer Services, 24, 1-9. https://doi.org/10.1016/j.jretconser.2015 .01 .008
Yuan, Y. H. Erin, \& Wu, C. K. (2008). Relationships Marketing, Experiential Value, Experiential Satisfaction, Customer. Journal of Hospitality \& Tourism Research, 32(3), 387-410. https://doi.org/10.1177/1096348008317 392

Zare, S. (2019). Cultural influences on memorable tourism experiences. Anatolia, 30(3), 316-327. https://doi.org/10.1080/13032917.2019. 1575886

Zhang, H., Wu, Y., \& Buhalis, D. (2018). A model of perceived image, memorable tourism experiences and revisit intention. Journal of Destination Marketing \& Management, 8, 326336. https://doi.org/10.1016/j.jdmm.2017.06.004 